\title{
НИКЕЛЬ: ПОТРЕБЛЕНИЕ И СОДЕРЖАНИЕ В КРОВИ СРЕДИ ГРУПП С РАЗЛИЧНЫМ ПИЩЕВЫМ ПОВЕДЕНИЕМ
}

\author{
Е.И. Сидорова, А.В. Гальченко ${ }^{2 *}$ \\ ${ }^{1}$ Первый Московский государственный медицинский университет \\ им. И.М. Сеченова Минздрава России (Сеченовский Университет), Москва, Россия \\ ORCID: 0000-0003-3361-2460, e-mail: elizavsid@ gmail.com \\ ${ }^{2}$ Российский университет дружбы народов, Москва, Россия \\ ORCID: 0000-0001-7286-5044 \\ *e-mail: gav.jina@gmail.com
}

РЕЗЮМЕ. Никель - это малоизученный микроэлемент. Обнаружена его роль в процессах кроветворения, регуляции гликемии и артериального давления. В настоящем исследовании анализировались сывороточные концентрации никеля и его поступление с пищей среди различных пищевых групп. Выявлено, что потребление никеля уменьшалось при снижении доли растительных продуктов. При этом его уровень в крови между группами не различался. Все испытуемые не превышали предельно допустимой концентрации.

КЛЮЧЕВЫЕ СЛОВА: веганы, вегетарианцы, Великий пост, православный пост, микроэлементы, микронутриенты, условно эссенциальные элементы.

\section{NICKEL: CONSUMPTION AND SERUM CONCENTRATIONS IN GROUPS WITH DIFFERENT NUTRITIONAL BEHAVIOR}

\author{
E.I. Sidorova ${ }^{1}$, A.V. Galchenko ${ }^{2 *}$ \\ ${ }^{1}$ I.M. Sechenov First Moscow State Medical University of the Ministry of Health of the Russian Federation \\ (Sechenov University), Moscow, Russian Federation \\ ORCID: 0000-0003-3361-2460, e-mail: elizavsid@gmail.com \\ ${ }^{2}$ Peoples' Friendship University of Russia, Moscow, Russian Federation \\ ORCID: 0000-0001-7286-5044 \\ *e-mail: gav.jina@gmail.com
}

\begin{abstract}
Nickel is a poorly studied trace element. Its role in the processes of hematopoesis, regulation of glycaemia and blood pressure is detected. In the present study, nickel serum concentrations and its dietary intake in various nutritional groups were analyzed. It was found that nickel consumption decreased with the reduction of the share of plant products, however, its blood levels did not differ. All subjects did not exceed recommended concentrations.

KEYWORDS: vegan, vegetarian, Great Lent, Orthodox fast, trace elements, micronutrients, relatively essential elements.
\end{abstract}

\section{ВВЕДЕНИЕ}

Никель - условно эссенциальный микроэлемент. Его содержание в организме варьируется от 1 (Морозова и др., 2011) до 10 мг (ATSDR, 2005), он относительно равномерно распределяется в тканях. Никель способен стимулировать кроветворение (Морозова и др., 2011), усиливать эффекты инсулина, а также снижать артериальное давление (Скальный, Рудаков, 2004; Оберлис и др., 2008). В то же время никель и некоторые его производные считаются канцерогенами (Alberti et al., 2003; Скальный, Рудаков, 2004; Оберлис и др., 2008).

\section{МАТЕРИАЛЫ И МЕТОДЫ}

Обследовано 185 человек: 46 веганов, 49 вегетарианцев, 42 человека, соблюдавших православный Великий пост и 48 людей на смешанном рационе. Различий по возрасту (33 [29;39]) или ИМТ $(22,4$ $[20,3 ; 23,8])$ между группами обнаружено не было. Все испытуемые подписали добровольное информированное согласие. Исследование одобрено комитетом по этике ФГБУН "ФИЦ питания, биотехнологии и безопасности пищи» (Протокол этического комитета № 6 от 22.12.2017) и выполнено в соответствии с Хельсинкской декларацией Всемирной медицинской ассоциации (1964 г.) и еe последующими поправками. 
Питание испытуемых из всех групп оценивали с помощью программы Nutrilogic (OOO, «Нутрилоджик», Россия).

В группах вегетарианцев, веганов и людей на смешанном рационе также определяли сывороточные концентрации никеля. Анализ проводили методом масс-спектрометрии с индуктивно-связанной плазмой (ICP-MS) на аппарате Nexion 300D (Perkin Elner, CША). Результаты сравнивали с референсными для данного метода значениями.

Расчеты и статистическую обработку выполняли в программе SPSS v. 23.0.0.0 (IBM, США). Распределение показателей в группах не было нормальным, поэтому использовали непараметрические методы сравнения: критерий Манна-Уитни для попарного сравнения и тест Краскела-Уоллиса для множественного сравнения. Для множественного сравнения также применяли поправку Бонферрони.

\section{РЕЗУЛЬТАТЫ И ОБСУЖДЕНИЕ}

Основными источниками никеля являются растительные продукты (Скальный, Рудаков, 2004; Оберлис и др., 2008). Закономерно, что вегетарианцы и веганы потребляли его больше, чем люди на смешанном рационе. Люди, соблюдавшие православный Великий пост, также потребляли меньше никеля, чем вегетарианцы и веганы. Вероятно, это обусловлено более однообразной растительной пищей, так как соблюдавшие православный Великий пост питались более консервативно и «макробиотично» по сравнению с вегетарианцами и веганами. При сравнении поступления никеля у вегетарианцев и веганов, обнаружено существенное отставание у последних (рис. 1). Похожие закономерности сохранялись и в других исследованиях (Юнацкая и др., 2015; Fleury et al., 2017). Однако в индийском исследовании были получены противоположные данные: Веганы потребляли значительно меньше никеля по сравнению с людьми, находящимися на смешанном рационе (Raghunath et al., 2006).

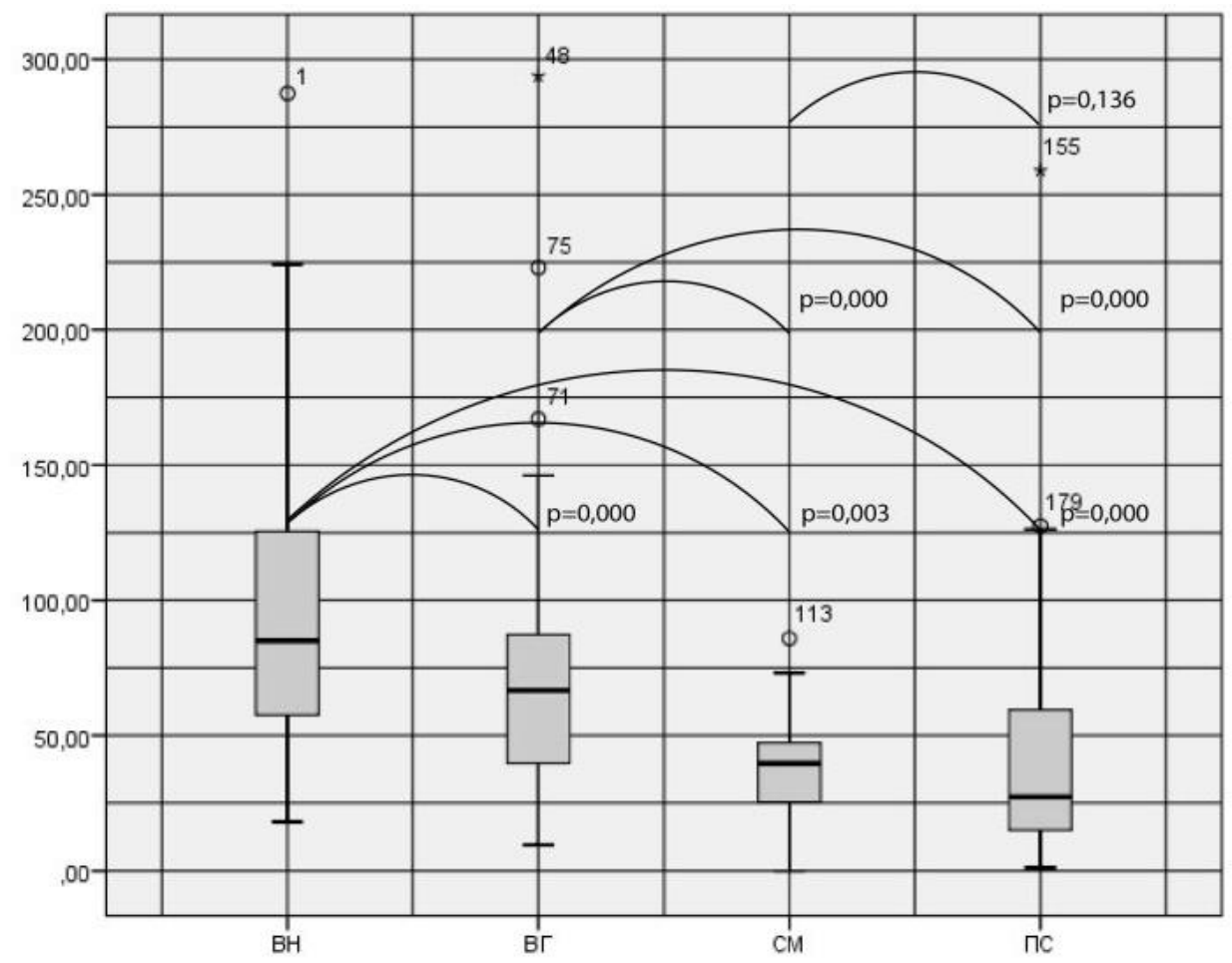

Pис. 1. Потребление никеля среди веганов (ВН), вегетарианцуев (ВГ), постящихся (ПС) и находящчихся на смешанном рационе (СМ) (мкг/сут)

В России нет принятых норм потребления никеля. Оптимальным уровнем его поступления считается 100-200 мкг/сут (Скальный, Рудаков, 2004; Оберлис и др., 2008). 
При изучении сывороточных концентраций никеля значимых различий между группами обнаружено не было. У всех испытуемых уровень никеля в крови не превышал предельно допустимых значений. Подробные результаты приведены на рис. 2.

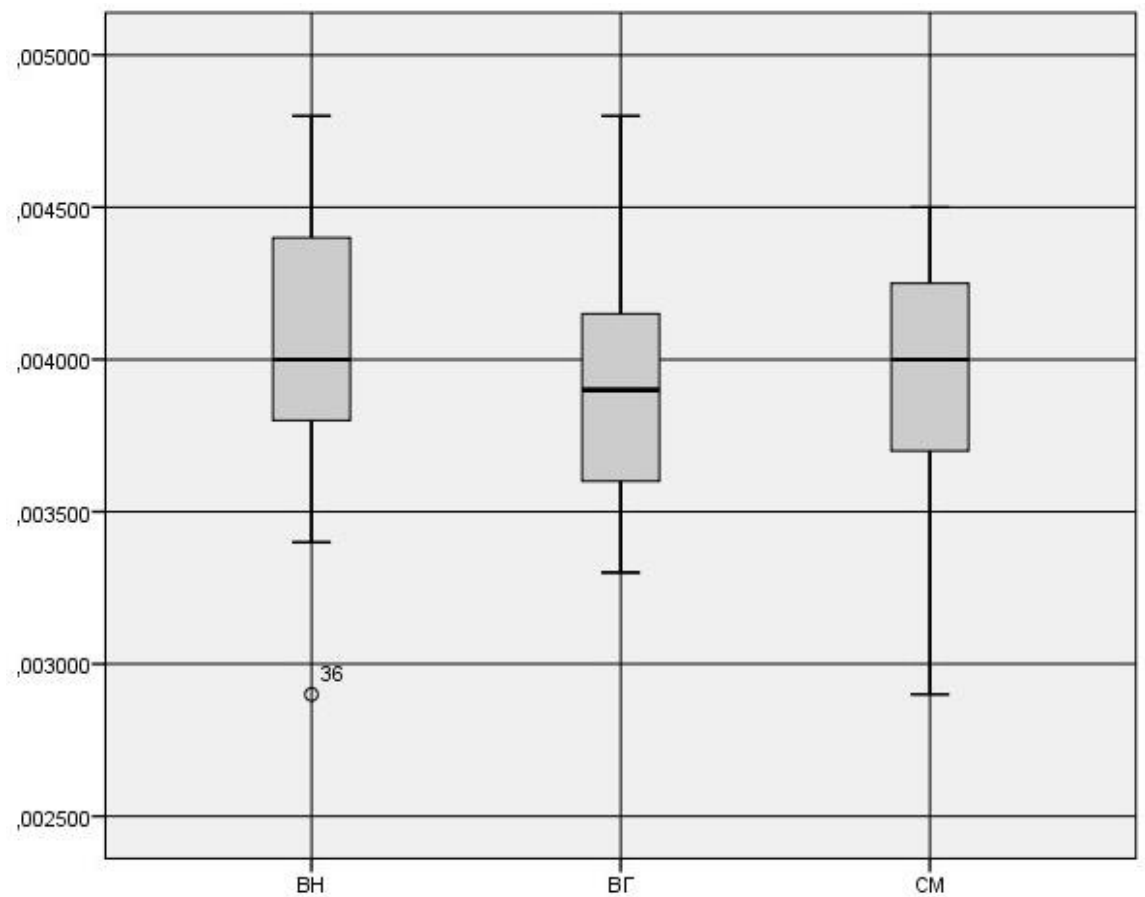

Pис. 2. Уровень никеля в крови среди (ВН), вегетарианцев (ВГ), постящихся (ПС) и находящихся на смешанном ращионе (СМ) (мкг/мл)

\section{ВЫВОДЫ}

Растительные рационы поставляют большие количества никеля. В целом, среди жителей Москвы его потребление и сывороточные концентрации не превышают допустимых значений. Однако требуются дополнительные исследования физиологии и эпидемиологии никеля для разработки нижних границ его содержания в крови, а также рекомендуемых норм потребления.

\section{Cиисок литературы / References}

1. Agency for Toxic Substances and Disease Registry (ATSDR). 2005. Toxicological profile for Nickel. Atlanta, GA: U.S. Department of Health and Human Services, Public Health Service.

2. Alberti F.A., Burini G., Perriello G., Fidanza F. Trace element intake and status of Italian subjects living in the Gubbio area. EnvironRes. 2003, 91:71-77.

3. Морозова Л.В. Химическиеэлементыворганизмечеловека: справочныематериалы. Под ред. МорозовойЛ.В. Архангельск: Издательский центр ПГУ им. М.В. Ломоносова, 2011. 44 с. (Morozova L.V. [Chemical elements in the human body: reference materials]. Arkhangelsk: Publishing Center PSU im. M.V. Lomonosov, 2011.44 p. (in Russ.)).

4. Оберлис Д., Харланд Б., Скальный А. Биологическаярольмакро- имикроэлементовучеловекаиживотных. СПб: Наука, 2008. 544 c. (Oberlis D., Harland B., Skalny A. [The biological role of macro- and trace elements in humans and animals]. SPb: Nauka, 2008. $544 \mathrm{p}$ (inRuss.)).

5. Скальный А.В., Рудаков И.А. Биоэлементы в медицине. М.: Мир, 2004. 272 c. (Skalny A.V., Rudakov I.A. [Bioelements in medicine]. M.: Mir, 2004. 272 p. (in Russ.)).

6. Юначкая Т.А., Турчанинова М.С., Костина Н.Н. Гигиеническая оценка питания вегетарианцев и лиц со смещанным питанием. Гигиенаисанитария. 2015; 9: 72-75. (Yunatskaya T.A., Turchaninova M.S., Kostina N.N. [Hygienic nutritional assessment of vegetarians and individuals with a dietary bias]. Gigienai sanitaria. 2015; 9: 72-75 (in Russ.)).

7. Fleury S., Rivière G., Allès B., Kesse-Guyot E., Méjean C., Hercberg S., Touvier M., Bemrah N. Exposure to contaminants and nutritional intakes in a French vegetarian population. Food and Chemical Toxicology. 2017; 109: 218-229. doi:10.1016/j.fct.2017.07.048.

8. Raghunath R., Tripathi R., Suseela B., Bhalke S., Shukla V., Puranik V. Dietary intake of metals by Mumbai adult population. Science of the Total Environment. 2006; 356(1-3): 62-68. doi:10.1016/j.scitotenv.2005.04.035. 